\title{
Optimal growth of Lactobacillus casei in a Cheddar cheese ripening model system requires exogenous fatty acids ${ }^{1}$
}

\author{
W. S. Tan, ${ }^{\star}$ M. F. Budinich, ${ }^{\star}$ R. Ward, $†$ J. R. Broadbent, $†$ and J. L. Steele ${ }^{\star 2}$ \\ *Department of Food Science, University of Wisconsin, Madison 53705 \\ †Department of Nutrition and Food Sciences, Utah State University, Logan 84322
}

\begin{abstract}
Flavor development in ripening Cheddar cheese depends on complex microbial and biochemical processes that are difficult to study in natural cheese. Thus, our group has developed Cheddar cheese extract (CCE) as a model system to study these processes. In previous work, we found that CCE supported growth of Lactobacillus casei, one of the most prominent nonstarter lactic acid bacteria (NSLAB) species found in ripening Cheddar cheese, to a final cell density of $10^{8} \mathrm{cfu} / \mathrm{mL}$ at $37^{\circ} \mathrm{C}$. However, when similar growth experiments were performed at $8^{\circ} \mathrm{C}$ in $\mathrm{CCE}$ derived from 4-mo-old cheese $(4 \mathrm{mCCE})$, the final cell densities obtained were only about $10^{6} \mathrm{cfu} / \mathrm{mL}$, which is at the lower end of the range of the NSLAB population expected in ripening Cheddar cheese. Here, we report that addition of Tween 80 to CCE resulted in a significant increase in the final cell density of $L$. casei during growth at $8^{\circ} \mathrm{C}$ and produced concomitant changes in cytoplasmic membrane fatty acid (CMFA) composition. Although the effect was not as dramatic, addition of milk fat or a monoacylglycerol (MAG) mixture based on the MAG profile of milk fat to $4 \mathrm{mCCE}$ also led to an increased final cell density of $L$. casei in $\mathrm{CCE}$ at $8^{\circ} \mathrm{C}$ and changes in CMFA composition. These observations suggest that optimal growth of $L$. casei in CCE at low temperature requires supplementation with a source of fatty acids (FA). We hypothesize that L. casei incorporates environmental FA into its CMFA, thereby reducing its energy requirement for growth. The exogenous FA may then be modified or supplemented with FA from de novo synthesis to arrive at a CMFA composition that yields the functionality (i.e., viscosity) required for growth in specific conditions. Additional studies utilizing the CCE model to investigate microbial contribu-
\end{abstract}

Received August 18, 2011.

Accepted December 26, 2011.

${ }^{1}$ Potential conflict of interest: Peggy Steele, a member of J. L. Steele's family, is employed by Danisco Inc. (New Century, KS), a supplier of cultures to the food industry.

${ }^{2}$ Corresponding author: jlsteele@wisc.edu tions to cheese ripening should be conducted in CCE supplemented with $1 \%$ milk fat.

Key words: nonstarter lactic acid bacteria, Lactobacillus casei, Cheddar cheese model system, cytoplasmic membrane fatty acid

\section{INTRODUCTION}

Lactic acid bacteria (LAB) present in ripening cheese include deliberately added starter LAB (SLAB) and adjunct cultures, as well as a large adventitious microbiota referred to as nonstarter LAB (NSLAB). Whereas SLAB and adjunct cultures are intentionally added to cheese milk, adventitious NSLAB enter cheese through the cheese milk or via contamination from the manufacturing environment. The NSLAB typically dominate the cheese microbiota after the first few weeks of ripening, increasing in number from 10 to $10^{4} \mathrm{cfu} / \mathrm{g}$ to about $10^{6}$ to $10^{8} \mathrm{cfu} / \mathrm{g}$ within 2 to 3 mo of ripening (Fox et al., 1998). Hence, unlike SLAB and adjuncts, the types and numbers of "wild" NSLAB cannot be easily controlled. Substantial heterogeneity exists within the NSLAB microbiota, at both the species and strain level, between different processing facilities and even between different manufacturing days within the same processing facility (Jordan and Cogan, 1993). Additionally, the NSLAB microbiota, through their metabolic end products and enzymes, are known to significantly contribute to Cheddar cheese flavor development, including flavor defects in Cheddar cheese. Therefore, this uncontrolled and variable microbiota can result in inconsistent cheese quality (Fox et al., 1998; Broadbent et al., 2003).

Flavor development in ripening Cheddar cheese is a complex microbial and biochemical process that is difficult to study in natural cheese. Therefore, the development of a model system that mimics the natural environment of cheese is required to analyze strainspecific contributions of SLAB and NSLAB to Cheddar cheese flavor development, as well as the effects of cheese composition and ripening regimen. In previous studies (Diaz-Muniz et al., 2006; Budinich et al., 2011), our laboratory developed a model system for cheese 
ripening based on Cheddar cheese extract (CCE), the aqueous fraction of cheese. Use of this model is founded on the assumption that the microorganisms that contribute to Cheddar cheese ripening utilize the watersoluble components present in the liquid phase of the cheese to meet their physiological needs. These studies evaluated growth of Lactobacillus casei, one of the most prominent NSLAB species (Mayra-Makinen and Bigret, 1998), in $\mathrm{CCE}$ at $37^{\circ} \mathrm{C}$, rather than at temperatures used for cheese ripening. However, the mesophilic bacteria that dominate the Cheddar cheese microbiota during ripening must be capable of growth at the lower ripening temperatures. The objective of this study was to evaluate the utility of this model system at $8^{\circ} \mathrm{C}$, a temperature typical of ripening Cheddar cheese.

\section{MATERIALS AND METHODS}

\section{Bacterial Strains}

The 4 L. casei strains used in this study were all isolated from ripening cheese. Lactobacillus casei ATCC 334 was obtained from the American Type Culture Collection (Rockville, MD), L. casei M36 (Boucher et al., 2006) and UW-4 were obtained from the Steele culture collection at the Department of Food Science of University of Wisconsin-Madison, and L. casei 7R1 was obtained from Department of Food Science of Royal Veterinary and Agriculture University (Frederiksberg $\mathrm{C}$, Denmark). Stock cultures were maintained at $-80^{\circ} \mathrm{C}$ in de Man, Rogosa, and Sharpe (MRS) broth medium (Difco Laboratories, Detroit, MI) with 25\% (vol/vol) glycerol. Working cultures were prepared from frozen stocks by consecutive transfers in MRS broth supplemented with 2\% (wt/vol) galactose (Sigma-Aldrich Co., St. Louis, MO) and CCE with $2 \%$ (wt/vol) galactose broth. Incubations were conducted statically at $37^{\circ} \mathrm{C}$ for 24 and 16 to $18 \mathrm{~h}$, respectively.

\section{CCE and Growth Conditions}

Preparation of 4-mo-old CCE (4mCCE) was conducted essentially as described previously (Díaz-Muñiz and Steele, 2006; Budinich et al., 2011) using grade A quality, 4-mo-old aged Cheddar cheese with low lactose, galactose, and moisture contents (Kiel Cheese LLC, St. Paul, MN). Freeze-dried $4 \mathrm{mCCE}$ was stored at $4^{\circ} \mathrm{C}$, reconstituted in distilled $\mathrm{H}_{2} \mathrm{O}(95 \mathrm{~g} / \mathrm{L})$ when needed, and stirred for 15 to $20 \mathrm{~min}$. The salt concentration of the $4 \mathrm{mCCE}$ was determined to be $3.1 \%$ using chloride QuanTab test strips (Hach, Loveland, CO). The citrate concentration of $4 \mathrm{mCCE}$ was determined to be 0.2 $\mathrm{m} M$ using the Citric Acid test kit (R-Biopharm Inc., Marshall, MI). If required, the $\mathrm{pH}$ of the $4 \mathrm{mCCE}$ was adjusted to $5.2 \pm 0.1$ with $1 \mathrm{~N} \mathrm{HCl}$. To achieve sterility, $4 \mathrm{mCCE}$ was filter-sterilized by using $0.2-\mu \mathrm{m}$ polyethersulfone membrane filter units (Nalgene, Rochester, NY) and stored at $4^{\circ} \mathrm{C}$ for not more than $24 \mathrm{~h}$ before use.

Lactobacillus casei growth studies were conducted in sterile 2-mL oxygen-free, crimped-top vials (National Scientific, Rockwood, TN). Bacterial cells from working cultures were washed twice using a $0.9 \% \mathrm{NaCl}$ solution containing $0.025 \%$ of $20 \%$ Triton-X-100, a nonionic wetting agent that decreases the surface tension between cells (Mallmann and Broitman, 1956; Sigma-Aldrich Co.), at $3,000 \times g$ for $8 \mathrm{~min}$ at $25^{\circ} \mathrm{C}$ and suspended in $1 \mathrm{~mL}$ of saline. Optical densities of the suspended cells were measured using SmartSpec Plus spectrophotometer (Bio-Rad Laboratories, Hercules, CA) and adjusted to 1.0; the cultures were subsequently diluted 100 times to achieve approximately $10^{4}$ to $10^{5} \mathrm{cfu} / \mathrm{mL}$ of washed culture. About $10 \%$ (vol/vol) of culture was inoculated into filter-sterilized $4 \mathrm{mCCE}$, and then 1-mL aliquots were placed into each of the crimped-top vials. Additionally, uninoculated $4 \mathrm{mCCE}$ controls were prepared and confirmed to be sterile at the end of all growth experiments. A vial was removed from the $8^{\circ} \mathrm{C}$ water bath every week or the $37^{\circ} \mathrm{C}$ incubator every 3 to $6 \mathrm{~h}$, diluted, and enumerated via the drop plate method on MRS agar (Mallmann and Broitman, 1956). Drop plating was conducted in triplicate using $20 \mu \mathrm{L}$ per drop, and plates were incubated aerobically at $37^{\circ} \mathrm{C}$ for $48 \mathrm{~h}$ before enumeration.

When needed, various supplements were added to $4 \mathrm{mCCE}$. Addition of protease peptone no.3 (10 g/L; Becton Dickinson and Co., Sparks, MD), yeast extract (5 g/L; Becton Dickinson and Co.), Tween 80 (1 mL/L), D-galactose $(20 \mathrm{~g} / \mathrm{L})$, glycerol $(1 \mathrm{~mL} / \mathrm{L})$, sodium acetate (trihydrate; $5 \mathrm{~g} / \mathrm{L}$ ), or sodium citrate (dehydrate; $2 \mathrm{~g} / \mathrm{L}$; all from Sigma-Aldrich Co.) was accomplished by dissolving the supplement in distilled $\mathrm{H}_{2} \mathrm{O}$, sterilizing at $121^{\circ} \mathrm{C}$ for $15 \mathrm{~min}$, adding $4 \mathrm{mCCE}(95 \mathrm{~g} / \mathrm{L})$, and finally filter-sterilizing. Addition of pyridoxal $\mathrm{HCl}$ (5 mg/L), pyridoxamine (5 mg/L), RPMI-1640 vitamin mixture $(20 \mathrm{~mL} / \mathrm{L})$, pre-sterilized stock solution of DLmevalonic acid lactone $(10 \mu \mathrm{l} / \mathrm{L}$; Sigma-Aldrich Co. $)$, or a milk-based monoacylglycerol (MAG) mixture was accomplished by adding these components directly into the reconstituted $4 \mathrm{mCCE}$, followed by filter-sterilization. Addition of milk fat was done directly into the vials.

\section{Milk Fat Preparation}

Milk fat was prepared from cream (Babcock Dairy, Department of Food Science, University of WisconsinMadison) using a procedure based upon Patton and Huston's (1986) method, modified by the incorpora- 
tion of additional washes. Cream was washed at room temperature with sterile PBS using a cream separator to remove any remaining milk. The cream was churned and washed twice with sterile PBS at $37^{\circ} \mathrm{C}$ for $15 \mathrm{~min}$ to separate the fat. The fat layer was separated and washed twice consecutively with distilled water and PBS at $4^{\circ} \mathrm{C}$. The solid milk fat was steamed twice for 20 min with a 2 -h incubation at $37^{\circ} \mathrm{C}$ between treatments, and stored at $-20^{\circ} \mathrm{C}$ until used.

\section{Milk Fat Analysis}

Separation of the 5 lipid classes [triacylglycerol (TAG), FFA, diacylglycerol (DAG), phospholipids (PL), and MAG] present in a milk fat isolate was conducted using a series of steps that began with lipid extraction. To start, $100 \mathrm{mg}$ of milk fat was mixed with $100 \mu \mathrm{L}$ of surrogate standards for each lipid class. Each surrogate standard was composed of a unique FA not typically found in milk. The lipids were then extracted using the Folch method (Folch et al., 1957), and the lower lipid-containing phase was collected. Next, the lipid classes were separated by thin layer chromatography. The silica plate was placed in $100^{\circ} \mathrm{C}$ oven for 10 min to activate the silica. The developing solvent was an 80:20:2 solution of hexane, diethyl ether, and formic acid, respectively. The bands were visualized by exposing the plate to iodine vapor and indentified according to their reported relative mobility in previous studies (Christie, 2000). Additionally, identities of bands were confirmed by the presence of the unique FA derived from the surrogate standard. Silica was scraped and the recovered individual classes of lipids from the thinlayer chromatography were analyzed as methyl esters by mixing scraped silica from TLC plate with $0.8 \mathrm{~mL}$ of hexane and $1.2 \mathrm{~mL}$ of $10 \%$ acetyl chloride in methanol. The mixture was incubated at $100^{\circ} \mathrm{C}$ for $40 \mathrm{~min}$; then, the solution was cooled to room temperature and $2 \mathrm{~mL}$ of $6 \%$ sodium carbonate solution and $0.4 \mathrm{~mL}$ of hexane were added. Fatty acid methyl esters (FAME) were extracted with $100 \mu \mathrm{L}$ of hexane and transferred to a GC vial. Two GC methods were employed using a Shimadzu GC (model QP2010, Shimadzu, Columbia, MD) with flame-ionization detector: one method for the TAG lipid class and another for the other lipid classes. The TAG method used a split injection with a ratio of 1:50 with an injection temperature of $250^{\circ} \mathrm{C}$. The temperature program was as follows: $35^{\circ} \mathrm{C}$ for 2 min, heated to $175^{\circ} \mathrm{C}$ at a rate of $40^{\circ} \mathrm{C} / \mathrm{min}$, holding for $4 \mathrm{~min}$, heated to $250^{\circ} \mathrm{C}$ at a rate of $3.5^{\circ} \mathrm{C} / \mathrm{min}$, and holding for $10 \mathrm{~min}$. For the other lipids classes, the injection temperature was $250^{\circ} \mathrm{C}$ with a split ratio of 1:10. The carrier gas was helium with a linear velocity of $56.4 \mathrm{~cm} / \mathrm{s}$. The temperature program was as follows: $50^{\circ} \mathrm{C}$ for $0.29 \mathrm{~min}$, heated to $180^{\circ} \mathrm{C}$ at a rate of $82^{\circ} \mathrm{C} /$ min, holding for $4 \mathrm{~min}$, heated to $220^{\circ} \mathrm{C}$ at a rate of $13.8^{\circ} \mathrm{C} / \mathrm{min}$, heated to $250^{\circ} \mathrm{C}$ at a rate of $35.54^{\circ} \mathrm{C} / \mathrm{min}$, and holding for $2 \mathrm{~min}$. The peaks were identified using an authentic methyl FA standard (Nu-Chek Prep Inc., Elysian, MN). The amount of each FFA in each class was determined by dividing the area of each FFA by the lipid class internal standard and multiplying that by the concentration of the internal standard.
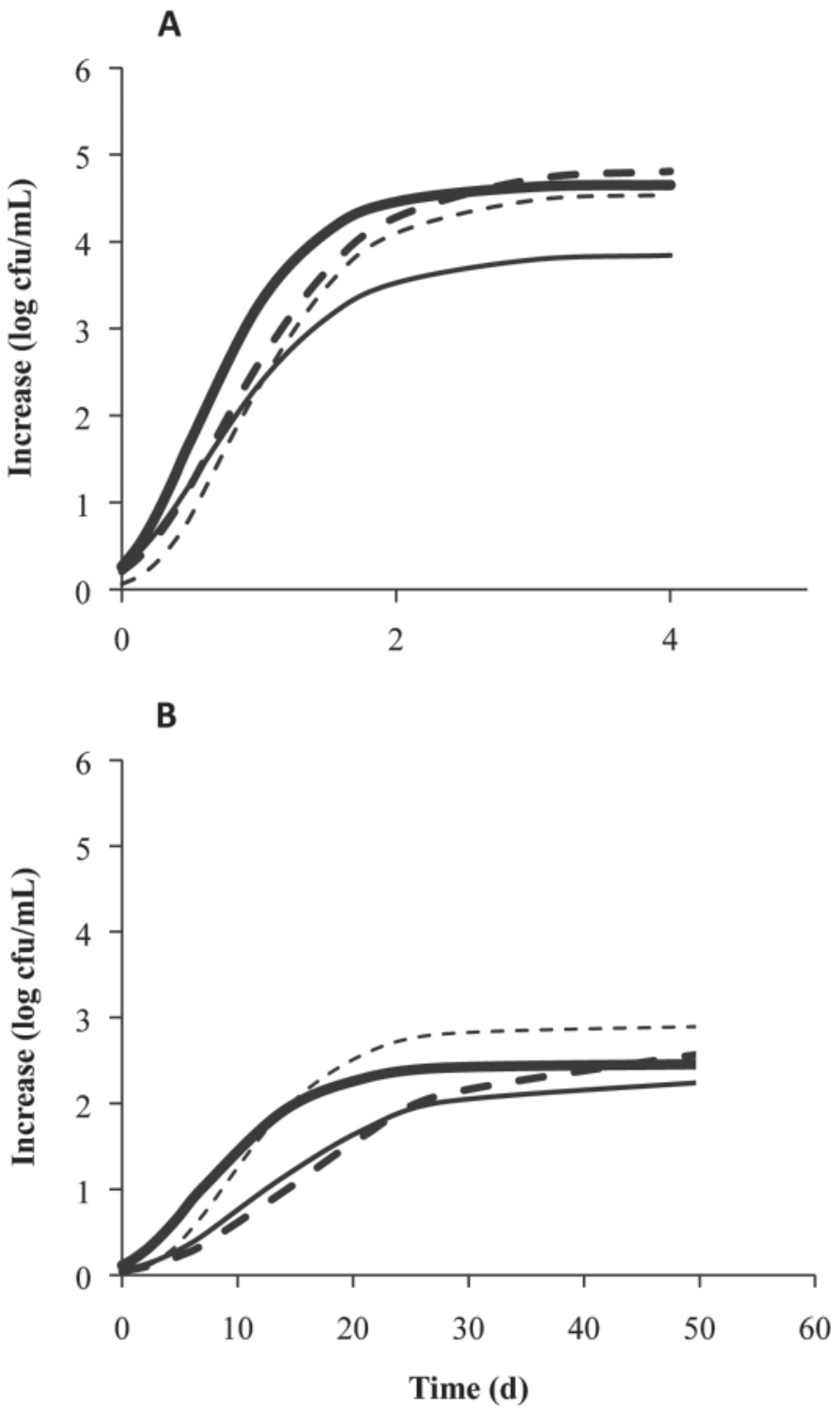

Figure 1. Effect of temperatures, (A) $37^{\circ} \mathrm{C}$ and (B) $8^{\circ} \mathrm{C}$, on growth of Lactobacillus casei strains in Cheddar cheese extract prepared from cheese aged $4 \mathrm{mo}(4 \mathrm{mCCE})$. Initial numbers ranged from approximately $3 \times 10^{3}$ to $1 \times 10^{4} \mathrm{cfu} / \mathrm{mL}$. Best fit lines for cell density during growth in Cheddar cheese extracts at 37 and $8^{\circ} \mathrm{C}$ of L. casei ATCC 334 (thin black line), M36 (thick black line), UW4 (short-dashed line), and 7R1 (long-dashed line) were obtained using the Gompertz growth model. 


\section{Preparation of MAG Stock Solution}

The MAG stock solution $(19.2 \mathrm{mg} / \mathrm{mL})$ was prepared by dissolving MAG salts [1-monolaurin $\left(\mathrm{C}_{12: 0}\right.$; $0.75 \mathrm{mg} / \mathrm{mL})$, monomyristine $\left(\mathrm{C}_{14: 0} ; 2.67 \mathrm{mg} / \mathrm{mL}\right)$, $\alpha$-monopalmitin $\left(\mathrm{C}_{16: 0} ; 9.26 \mathrm{mg} / \mathrm{mL}\right)$, monostearin $\left(\mathrm{C}_{18: 0} ; 3.45 \mathrm{mg} / \mathrm{mL}\right)$, and monoolein $\left(\mathrm{C}_{18: \ln 9 \mathrm{c}}\right.$, where $\mathrm{c}=$ cis; $3.12 \mathrm{mg} / \mathrm{mL}$ )] in dimethylsulfoxide (Sigma-Aldrich Co.) at the same concentration (density of $0.88 \mathrm{~g} /$ $\mathrm{mL}$ ) as DAG and MAG were measured in the milk fat sample (Supplemental Table S1, available online at http://www.journalofdairyscience.org/). Dilutions of stock solutions were prepared using dimethylsulfoxide as the diluent.

\section{Cytoplasmic Membrane Fatty Acid Analysis}

Bacterial FA were analyzed as methyl esters according to the method of O'Fallon et al. (2007). Bacterial pellets were resuspended in $530 \mu \mathrm{L}$ of methanol and transferred to a $1.5-\mathrm{mL}$ amber glass vial; $70 \mu \mathrm{L}$ of 10 $N \mathrm{KOH}$ was added. Samples were vortexed for $30 \mathrm{~s}$ and incubated in a shaking water bath at $150 \mathrm{rpm}$ at $55^{\circ} \mathrm{C}$ for $1.5 \mathrm{~h}$. After incubation, samples were cooled and $58 \mu \mathrm{L}$ of $24 \mathrm{~N} \mathrm{H}_{2} \mathrm{SO}_{4}$ was added, and the samples were incubated for another $1.5 \mathrm{~h}$ in a shaking water bath at $150 \mathrm{rpm}$ at $55^{\circ} \mathrm{C}$. The FAME were extracted with hexane $(300 \mu \mathrm{L})$ and transferred into a $2-\mathrm{mL}$ GC vial. The FAME were analyzed by $\mathrm{GC}$ with a flameionization detector (model QP2010, Shimadzu Co.) using a standard method for FAME (O'Fallon et al., 2007). Samples containing methyl esters in hexane (1 $\mu \mathrm{L})$ were injected onto an HP-88 fused silica $100 \mathrm{~m} \times$ $0.25 \mathrm{~mm}$ column, with $0.20-\mu \mathrm{m}$ film thickness (Agilent Technologies, Palo Alto, CA). The injection port was maintained at $250^{\circ} \mathrm{C}$ in the split mode, and the sample was split at a 10:1 ratio with a $3.0 \mathrm{~mL} / \mathrm{min}$ purge flow.
Hydrogen was used as the carrier gas at a linear velocity of $41.1 \mathrm{~cm} / \mathrm{s}$. The temperature program was as follows: initial temperature $35^{\circ} \mathrm{C}$ and hold for $2 \mathrm{~min}$, increase at $40^{\circ} \mathrm{C} / \mathrm{min}$ to $175^{\circ} \mathrm{C}$ and hold for $4 \mathrm{~min}$, increase at $3.5^{\circ} \mathrm{C} / \mathrm{min}$ to $240^{\circ} \mathrm{C}$ and hold for $25 \mathrm{~min}$. The detector was operated at $250^{\circ} \mathrm{C}$ and makeup gas was nitrogen $30 \mathrm{~mL} / \mathrm{min}$. Air and hydrogen flow to the detector was 450 and $40 \mathrm{~mL} / \mathrm{min}$, respectively. Total run time was $53.07 \mathrm{~min} /$ sample. Peaks were identified according to retention time utilizing several standard FAME mixes (Nu-Chek Prep Inc.). Raw peak areas were converted to concentrations using response factors generated with the standard FAME mixtures.

\section{Statistical Analysis}

Growth studies were conducted in triplicate. Bacterial numbers were calculated as the mean values from triplicate samples. Growth parameters (maximum cell density, growth rate, and lag phase) and curve model fitting were obtained with Gompertz growth model (Zwietering et al., 1990) and derived using Tablecurve 2D, version 5.02 (Systat Software Inc., San Jose, CA) as described by Budinich et al. (2011). Statistical analysis of the final cell densities (cfu/mL) was done using Student's t-test, ANOVA, and Tukey's multiple comparison tests (Tukey, 1949). Results are reported as significantly different when the $P$-value was $<0.05$.

\section{RESULTS AND DISCUSSION}

\section{Effect of Temperature on Growth of $L$. casei Strains in $4 m C C E$}

Ripening Cheddar cheese is a complex and dynamic environment, which makes it difficult to determine the strain-specific contributions of SLAB and NSLAB to

Table 1. Growth parameters (means and standards deviations in parentheses) of Lactobacillus casei strains incubated at 8 and $37^{\circ} \mathrm{C}$ for 49 and $4 \mathrm{~d}$, respectively, in Cheddar cheese extract prepared from cheese aged 4 mo (4mCCE)

\begin{tabular}{|c|c|c|c|c|c|c|c|c|}
\hline Growth parameter $^{2}$ & \multicolumn{8}{|c|}{ 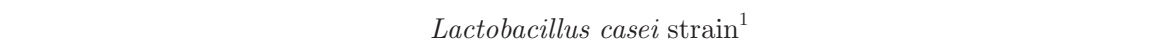 } \\
\hline Lag phase $(d)$ & $\begin{array}{l}62.2 \\
(26.3)^{\mathrm{a}}\end{array}$ & $\begin{array}{l}0.0 \\
(4.51)^{\mathrm{b}}\end{array}$ & $\begin{array}{c}16.8 \\
(13.3)^{\mathrm{a}}\end{array}$ & $\begin{array}{l}0.6 \\
(1.7)^{\mathrm{b}}\end{array}$ & $\begin{array}{l}80.0 \\
(27.1)^{\mathrm{a}}\end{array}$ & $\begin{array}{l}5.9 \\
(2.4)^{\mathrm{b}}\end{array}$ & $\begin{array}{l}100.0 \\
(36.2)^{\mathrm{a}}\end{array}$ & $\begin{array}{l}2.2 \\
(2.2)^{\mathrm{b}}\end{array}$ \\
\hline Growth $\operatorname{rate}^{3}$ (log cfu/mL per day) & $\begin{array}{c}0.0 \\
(0.0)^{\mathrm{a}}\end{array}$ & $\begin{array}{c}0.1 \\
(0.0)^{\mathrm{b}}\end{array}$ & $\begin{array}{c}0.0 \\
(0.0)^{\mathrm{a}}\end{array}$ & $\begin{array}{c}0.2 \\
(0.0)^{\mathrm{b}}\end{array}$ & $\begin{array}{c}0.0 \\
(0.0)^{\mathrm{a}}\end{array}$ & $\begin{array}{c}0.1 \\
(0.0)^{\mathrm{b}}\end{array}$ & $\begin{array}{c}0.0 \\
(0.0)^{\mathrm{a}}\end{array}$ & $\begin{array}{c}0.1 \\
(0.0)^{\mathrm{b}}\end{array}$ \\
\hline
\end{tabular}

\footnotetext{
${ }^{\mathrm{a}, \mathrm{b}}$ Means in each row within each strain with different superscripts differ $(P<0.05)$.

${ }^{1}$ Initial numbers ranged from approximately $3 \times 10^{3}$ to $1 \times 10^{4} \mathrm{cfu} / \mathrm{mL}$.

${ }^{2}$ Growth parameters were obtained using Gompertz growth model.

${ }^{3} \mathrm{~A}$ value of 0.0 indicates that growth rate was $<0.1 \log \mathrm{cfu} / \mathrm{mL}$ per day.
} 
A
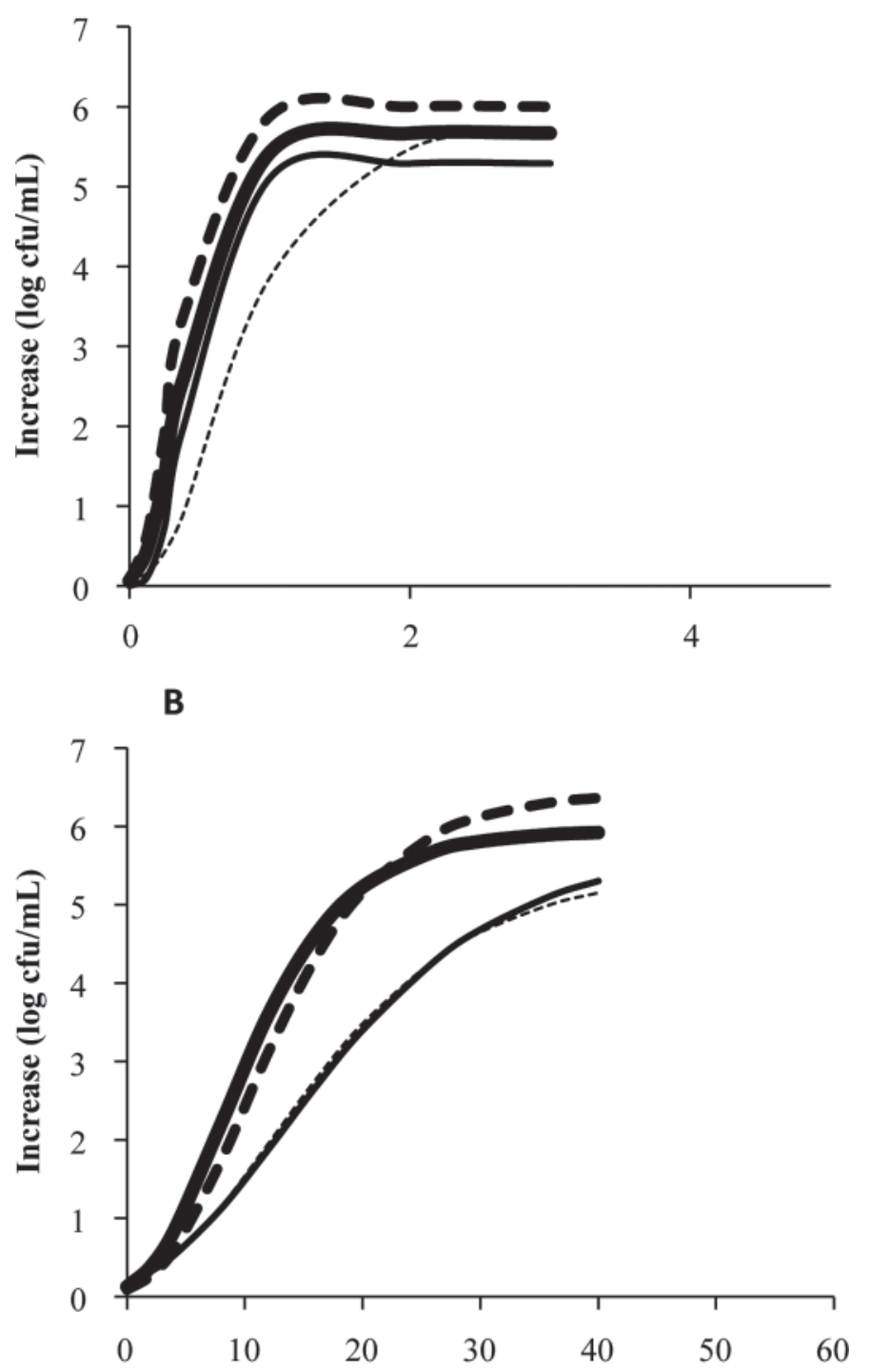

Time (d)

Figure 2. Effect of temperatures, $37^{\circ} \mathrm{C}(\mathrm{A})$ and $8^{\circ} \mathrm{C}(\mathrm{B})$, on the growth of Lactobacillus casei strains in de Man, Rogosa, and Sharpe media. Initial numbers ranged from approximately $3 \times 10^{3}$ to $1 \times 10^{4}$ $\mathrm{cfu} / \mathrm{mL}$. Best fit lines for cell density during growth in Cheddar cheese extracts at 37 and $8^{\circ} \mathrm{C}$ of $L$. casei ATCC 334 (thin black line), M36 (thick black line), UW4 (short-dashed line), and 7R1 (long-dashed line) were obtained using the Gompertz growth model.

Cheddar cheese flavor development, as well as the effects of cheese composition and ripening regimen on Cheddar cheese microbiota and flavor development. To address these challenges, we developed the CCE model system and demonstrated that it supported growth of $L$. casei ATCC 334 to final cell densities of $10^{8}$ to $10^{9} \mathrm{cfu} / \mathrm{mL}$ at $37^{\circ} \mathrm{C}$ (Díaz-Muñiz et al., 2006). In this study, we compared growth of several L. casei strains in $4 \mathrm{mCCE}$ at $37^{\circ} \mathrm{C}$ for $4 \mathrm{~d}$ and $8^{\circ} \mathrm{C}$ for $49 \mathrm{~d}$ (Figure

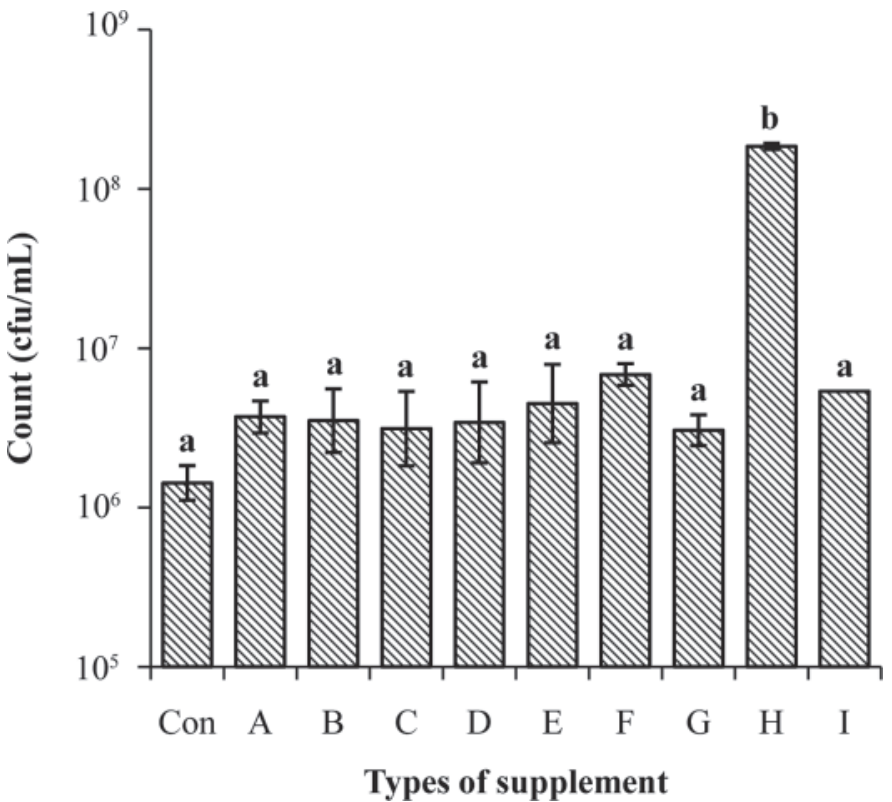

Figure 3. Effect of supplementation on the final cell density attained by Lactobacillus casei M36 in Cheddar cheese extract prepared from cheese aged $4 \mathrm{mo}(4 \mathrm{mCCE})$ at $8^{\circ} \mathrm{C}$. Initial numbers were approximately $1 \times 10^{4} \mathrm{cfu} / \mathrm{mL}$ and incubation was conducted for $7 \mathrm{wk}$. Error bars indicate standard deviation of data obtained in triplicate. Statistical analyses between treatments were conducted with Tukey's multiple comparison test. Treatments with different letters are statistically different from each other $(P<0.05)$. Control $(\mathrm{Con})=$ no supplement; $\mathrm{A}=\mathrm{D}$-galactose; $\mathrm{B}=$ mixture of glycerol and DL-mevalonic acid lactone; $\mathrm{C}=$ protease peptone no. $3 ; \mathrm{D}=$ mixture of pyridoxal $\mathrm{HCl}$ and pyridoxamine; $\mathrm{E}=\mathrm{RPMI}-1640$ vitamin mixture; $\mathrm{F}=$ mixture of sodium acetate and sodium citrate; $\mathrm{G}=$ yeast extract; $\mathrm{H}=$ Tween $80 ; \mathrm{I}=1 \%$ milk fat.

1; Table 1). The growth parameters lag phase, growth rate $(\mu \max )$, and final cell density were obtained using the Gompertz growth model (Zwietering et al., 1990). Statistical analysis of growth parameters for each strain at 8 and $37^{\circ} \mathrm{C}$ were conducted using paired Student $t$ test. All growth parameters of all 4 strains examined at 8 and $37^{\circ} \mathrm{C}$ were statistically different $(P<0.05)$. These results demonstrate that temperature had a significant effect on the final cell densities attained in $4 \mathrm{mCCE}$.

The final cell densities attained at $8^{\circ} \mathrm{C}$ (an average of $4.3 \times 10^{6} \mathrm{cfu} / \mathrm{mL}$ ) were at the lower end of the range of the NSLAB population expected in ripening Cheddar cheese, which typically reach $10^{6}$ to $10^{8} \mathrm{cfu} / \mathrm{g}$ within several weeks of ripening (Fox et al., 1998). This level is equivalent to approximately $2 \times 10^{6}$ to $2 \times 10^{8} \mathrm{cfu} /$ $\mathrm{mL}$ in $4 \mathrm{mCCE}$, accounting for the fact that Cheddar cheese contains $37 \%$ moisture. As expected, the length of the lag phase was significantly $(P<0.05)$ longer and growth rates significantly $(P<0.05)$ lower in $4 \mathrm{mCCE}$ at 8 versus $37^{\circ} \mathrm{C}$ (Table 1 ). However, when similar growth studies were conducted in MRS at 8 and $37^{\circ} \mathrm{C}$, no significant difference in the final cell densities was 
observed (Figure 2). These results suggest that growth of $L$. casei strains in $4 \mathrm{mCCE}$ at $8^{\circ} \mathrm{C}$ was limited by the absence of one or more essential nutrients and that this nutrient was lost during CCE preparation.

\section{Effect of Various Supplements on Growth of $L$. casei M36 in 4mCCE}

To identify the limiting nutrient for growth of $L$. $c a-$ sei in $4 \mathrm{mCCE}$ at $8^{\circ} \mathrm{C}$, growth studies were conducted at $8^{\circ} \mathrm{C}$ in $4 \mathrm{mCCE}$ containing a variety of supplements known to influence the growth of lactobacilli. Lactobacillus casei M36 was selected as the test organism based upon its growth characteristics in $4 \mathrm{mCCE}$ (Figure 1B). Supplements were selected from components of MRS (de Man et al., 1960) or the lactobacilli chemically defined media described by Christensen and Steele (2003). The supplements evaluated were protease peptone no. 3, yeast extract, D-galactose, Tween 80 , glycerol, sodium acetate (trihydrate), sodium citrate, pyridoxal $\mathrm{HCl}$, pyridoxamine, RPMI-1640 vitamin mixture, and DLmevalonic acid lactone. The effect of these nutrients on growth of $L$. casei $\mathrm{M} 36$ at $8^{\circ} \mathrm{C}$ in $4 \mathrm{mCCE}$ is presented in Figure 3. Interestingly, addition of galactose to $4 \mathrm{mCCE}$ did not significantly increase the final cell density of $L$. casei M36, suggesting that energy is not limiting for growth in $4 \mathrm{mCCE}$ at $8^{\circ} \mathrm{C}$. This result is in agreement with the observation by Budinich et al. (2011) that CCE lacking detectable levels of lactose and galactose was able to support the growth of $L$. casei ATCC 334 to final cell densities of $>1 \times 10^{8} \mathrm{cfu} / \mathrm{mL}$. As shown in Figure 3 , the only supplement that significantly $(P<$ $0.05)$ enhanced growth of $L$. casei M36 in 4mCCE at $8^{\circ} \mathrm{C}$ was Tween 80 . Tween 80 is a mixture of FA esters of polyoxyethelene sorbitan that contain approximately $20 \%$ FA by mass. Supplementation with Tween 80 produced a 100-fold increase final cell density compared with the control, and more than 50-fold increase in final cell density compared with the other supplements examined. The finding that Tween 80 is required for $L$. casei M36 to attain a final cell density in $4 \mathrm{mCCE}$ at $8^{\circ} \mathrm{C}$ typical of NSLAB populations in cheese suggests that exogenous FA are important for growth of $L$. casei in ripening cheese.

\section{Effect of Milk Fat and MAG Supplementation on Growth of $L$. casei Strains in $4 m C C E$}

The most likely source of FA to support growth of lactobacilli in ripening cheese is milk fat; therefore we explored whether addition of $0.1,1$, or $10 \%$ milk fat (vol/vol) to $4 \mathrm{mCCE}$ would enhance growth of M36 at $8^{\circ} \mathrm{C}$. Results confirmed that addition of 1 or $10 \%$ milk fat produced a significant $(P<0.05)$ increase in the final cell densities of $L$. casei $\mathrm{M} 36$ in $4 \mathrm{mCCE}$ at $8^{\circ} \mathrm{C}$, whereas no statistical change $(P>0.05)$ was observed with $0.1 \%$ milk fat (Figure 4 ). These observations indicated that CCE supplementation with $1 \%$ milk fat allowed L. casei M36 to reach the final cell densities expected in ripening Cheddar cheese.

To determine if this response was strain-specific, growth studies were performed at $8^{\circ} \mathrm{C}$ in $4 \mathrm{mCCE}$ with $1 \%$ milk fat with 3 additional $L$. casei strains. As shown in Figure 5, milk fat addition significantly $(P<0.05)$ enhanced the final cell density in $4 \mathrm{mCCE}$ of all strains tested by 5 - to 10 -fold over that observed in unsupplemented $4 \mathrm{mCCE}$. The largest increase was observed with $L$. casei M36 (10-fold), and the smallest increased was observed with $L$. casei ATCC 334 (5-fold). These results support the hypothesis that supplementation of $4 \mathrm{mCCE}$ with milk fat provides a source of exogenous FA that allows $L$. casei strains to reach the final cell densities expected in ripening Cheddar cheese.

The genome sequence of $L$. casei ATCC 334 contains 4 genes encoding esterases but no gene encoding a lipase (Makarova et al., 2006; Cai et al., 2009); therefore, MAG, DAG, and FFA are the most likely components of milk fat used by $L$. casei as sources of exogenous FA. To test this hypothesis, growth studies were conducted in CCE supplemented with a MAG solution that con-

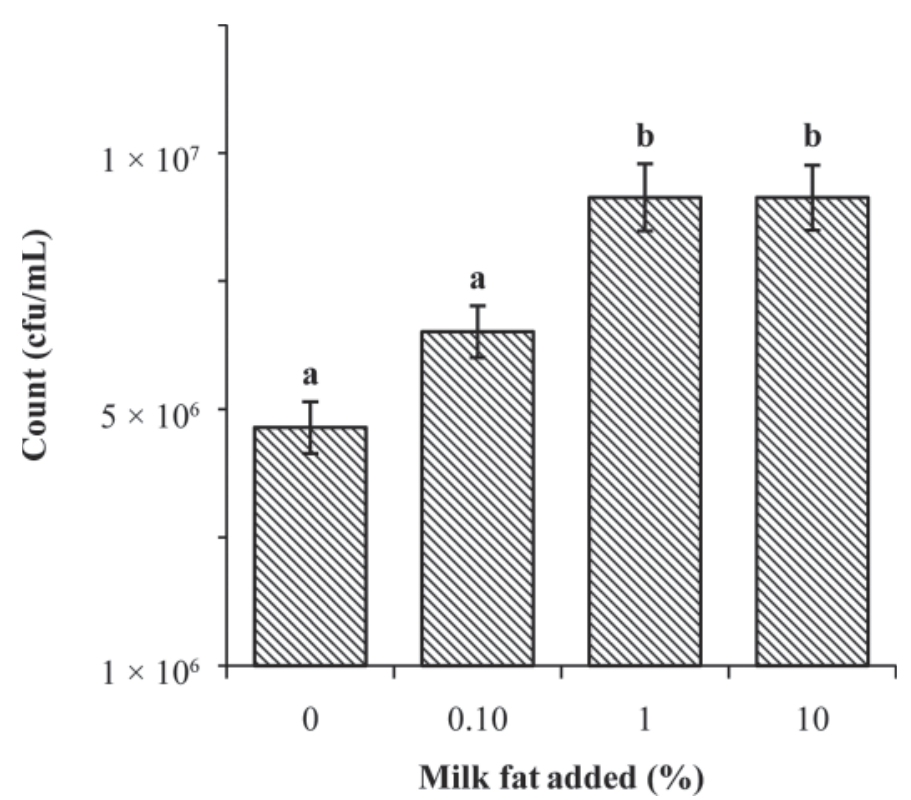

Figure 4. Effect of different percentage of milk fat addition on the final cell density of Lactobacillus casei M36 in Cheddar cheese extract prepared from cheese aged $4 \mathrm{mo}(4 \mathrm{mCCE})$ at $8^{\circ} \mathrm{C}$. Initial numbers were approximately $1 \times 10^{4} \mathrm{cfu} / \mathrm{mL}$ and incubation was conducted for $7 \mathrm{wk}$. Error bars indicate standard deviation of data obtained in triplicate. Statistical analysis between treatments was conducted with Tukey's multiple comparison test. Treatments with different letters are statistically different from each other $(P<0.05)$. 


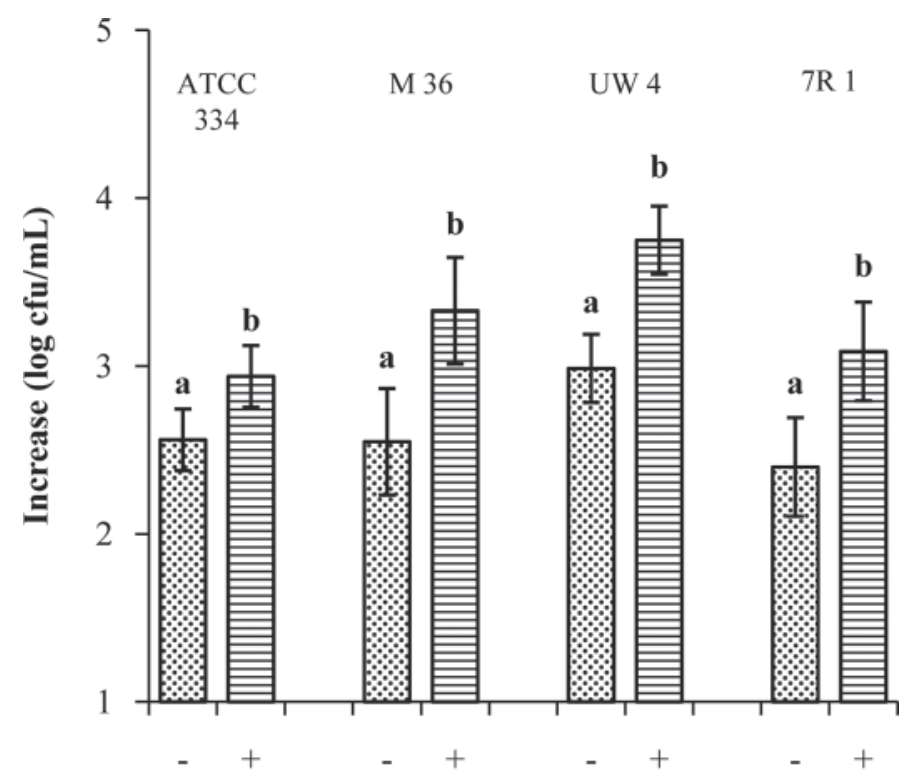

Presence of milk fat

Figure 5. Effect of $1 \%$ milk fat addition $(+)$ or not $(-)$ on the final cell density of Lactobacillus casei strains in Cheddar cheese extract prepared from cheese aged $4 \mathrm{mo}(4 \mathrm{mCCE})$ at $8^{\circ} \mathrm{C}$. Initial numbers were approximately $5 \times 10^{3}$ to $3 \times 10^{4} \mathrm{cfu} / \mathrm{mL}$ and incubation was conducted for $7 \mathrm{wk}$. Error bars indicate standard deviation of data obtained in triplicate. Statistical analysis between treatments of each strain was conducted with Student $t$-test. Treatments with different letters are statistically different from each other within each strain $(P$ $<0.05)$.

tained the $5 \mathrm{FA}$ present at the highest concentration in the PL/MAG and DAG fractions of the milk fat sample examined (Supplemental Table S1, available online at http://www.journalofdairyscience.org/). However, as MAG are known to be bacterial inhibitors (Wang and Johnson, 1992), preliminary growth experiments were conducted with L. casei M36 in CCE (due to limitations in the quantity of $4 \mathrm{mCCE}$, a different batch was used in these preliminary experiments) at $37^{\circ} \mathrm{C}$ with a broad range of MAG concentrations (Supplemental Figure 1, available online at http://www.journalofdairyscience. org/). The results indicated that the MAG mixture had no effect on growth at the lowest level examined $(0.19 \mu \mathrm{g} / \mathrm{mL})$, stimulated growth at $1.90 \mu \mathrm{g} / \mathrm{mL}$, and was inhibitory at the higher levels examined (19.0, 63.0, and $193 \mu \mathrm{g} / \mathrm{mL}$ ). Therefore, L. casei M36 $8^{\circ} \mathrm{C}$ growth experiments were conducted in $4 \mathrm{mCCE}$ supplemented with $1.90 \mu \mathrm{g} / \mathrm{mL}$ of the MAG mixture. The results of these growth experiments (Figure 6) were that the growth enhancement of M36 in 4mCCE with MAG was indistinguishable from that observed with $1 \%$ milkfat. These results strongly suggest that the $L$. casei growthstimulating component of milk fat is MAG, DAG, or FFA and that these FA sources are important nutrients for NSLAB growth in ripening cheese.

\section{Membrane FA Composition of $L$. casei M36 Under Different Growth Conditions}

The cytoplasmic membrane fatty acid (CMFA) composition of a bacterial cell is determined by de novo FA synthesis, incorporation of exogenous FA, and modification of existing CMFA (Zhang and Rock, 2008). To determine if $L$. casei M36 incorporated exogenous FA added as supplements to $4 \mathrm{mCCE}$, we examined the FA composition of the CMFA of M36 grown with different FA containing supplements (Table 2). Oleic acid $\left(\mathrm{C}_{18: \ln 9 \mathrm{c}}\right)$ accounted for $90 \%$ of the FA present in Tween 80, and L. casei is known to contain cyclopropane synthase, which catalyzes the addition of a methylene residue across the cis double bond of unsaturated FA such as $\mathrm{C}_{18: \ln 9 \mathrm{c}}$ to form cyclopropane fatty acids (CFA), such as dihydrosterulic acid $\left(\mathrm{C}_{19: 0 \Delta 9 \mathrm{c}}\right.$; Suutari and Laakso, 1992; Broadbent et al., 2010). Oleic and dihydrosterulic acids account for $17 \%$ of the total FA present in the CMFA of cells grown in $4 \mathrm{mCCE}$ at $8^{\circ} \mathrm{C}$ without supplementation, whereas these FA account for $62.5 \%$ of the FA present in the CMFA of cells grown

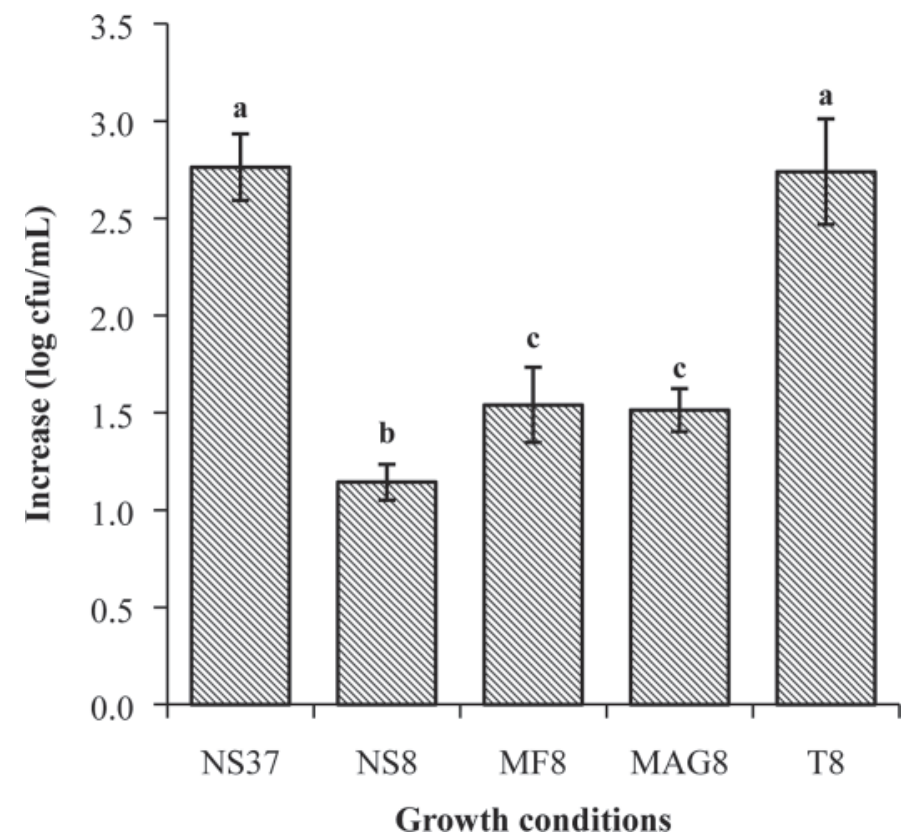

Figure 6. Effect of different supplementation and growth conditions on the growth of Lactobacillus casei M36 in Cheddar cheese extract prepared from cheese aged $4 \mathrm{mo}(4 \mathrm{mCCE})$. Initial number was approximately $4 \times 10^{4} \mathrm{cfu} / \mathrm{mL}$. NS37 and NS8 $=$ no supplementation at growth temperature of $37^{\circ} \mathrm{C}$ and $8^{\circ} \mathrm{C} ; \mathrm{MF} 8=$ supplementation with $1 \%$ milk fat at growth temperature of $8^{\circ} \mathrm{C}$; MAG8 $=$ supplementation with monoglyceride solution $(1.90 \mu \mathrm{g} / \mathrm{mL})$ at growth temperature of $8^{\circ} \mathrm{C}$; T8 $=$ supplementation with $0.1 \%$ Tween 80 at growth temperature of $8^{\circ} \mathrm{C}$. Error bars indicate standard deviation of data obtained in triplicate. Statistical analysis between treatment and control was conducted with Student $t$-test. Treatments with different letters are statistically different from each other $(P<0.05)$. 
in $4 \mathrm{mCCE}$ at $8^{\circ} \mathrm{C}$ supplemented with Tween 80 (Table 2). Similarly, the predominant FA present in MAG solution used in the growth experiments was palmitic acid $\left(\mathrm{C}_{16: 0}\right)$. This $\mathrm{FA}$ accounts for $29.1 \%$ of the total FA present in the CMFA of cells grown in $4 \mathrm{mCCE}$ at $8^{\circ} \mathrm{C}$ without supplementation, whereas it accounts for $60.4 \%$ of the FA present in the CMFA of cells grown in $4 \mathrm{mCCE}$ at $8^{\circ} \mathrm{C}$ supplemented with the MAG solution (Table 2). These results clearly demonstrate that $L$. casei M36 incorporates exogenous FA into its cytoplasmic membrane during growth in $4 \mathrm{mCCE}$ at $8^{\circ} \mathrm{C}$. Because FA biosynthesis in bacteria is an energy-intensive process (Zhang and Rock, 2008), the incorporation of exogenous FA represents a significant energy savings to the cell and likely explains the growth enhancement these supplements provide at $8^{\circ} \mathrm{C}$ in $4 \mathrm{mCCE}$.

The incorporation of exogenous FA into the cytoplasmic membrane will also have a significant effect on membrane function. In many bacteria, the ability to grow at sub-optimal temperatures requires homoviscous adaptation of the cytoplasmic membrane, which is manifest through alterations in the CMFA profile (Farrell and Rose, 1967; Kaneda, 1991; Annous et al., 1997; Sajbidor, 1997; Chattopadhyay and Jagannadham, 2003; Hulbert, 2003; Zhang and Rock, 2008). These alterations include changes in the average FA chain length, percentage CFA, percentage branchedchain FA (BCFA), ratio of iso:anteiso (I:A), percentage PUFA, and ratio of unsaturated to saturated FA (U:S ratio). The adaptation of $L$. casei M36 to growth at $8^{\circ} \mathrm{C}$, a sub-optimal temperature, is apparent by comparing the CMFA profile of this organism after growth in unsupplemented $4 \mathrm{mCCE}$ at $8^{\circ} \mathrm{C}$ to that observed after growth at $37^{\circ} \mathrm{C}$. The most obvious difference was the dramatic increase in the percentage of BCFA in the cytoplasmic membrane when this organism was

Table 2. Cytoplasmic membrane FA profiles of Lactobacillus casei M36 propagated in Cheddar cheese extract prepared from cheese aged 4 mo (4mCCE) under different conditions

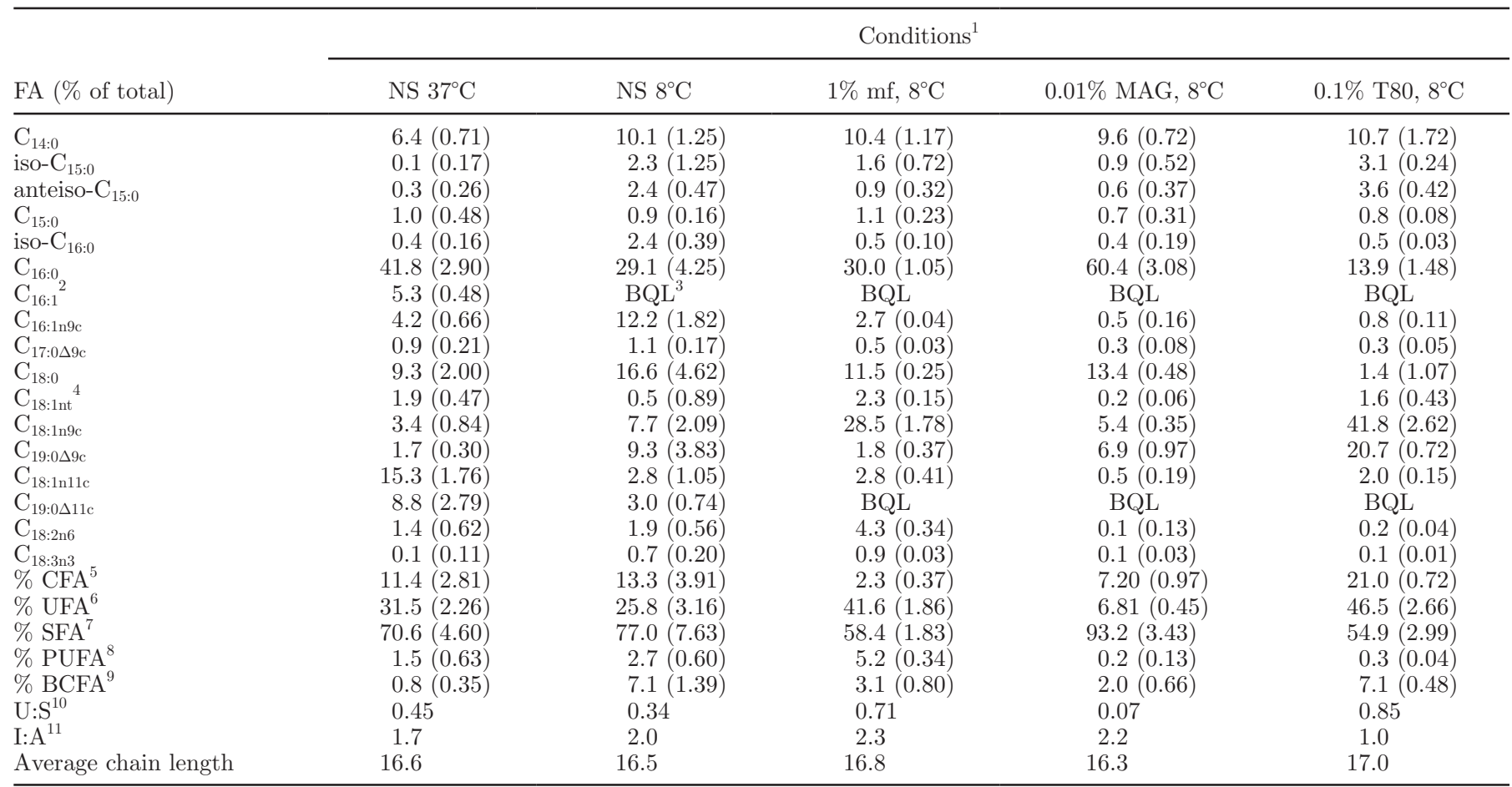

${ }^{1} \mathrm{NS}=$ no supplement; $\mathrm{mf}=1 \%$ milk fat; $\mathrm{MAG}=0.01 \%$ monoglyceride; $0.1 \%$ T $80=0.1 \%$ Tween 80 .

${ }^{2}$ Double bond position unknown.

${ }^{3} \mathrm{BQL}=$ below quantifiable limit $(0.002 \%)$.

${ }^{4}$ Mixture of isomers.

${ }^{5}$ Cyclopropane fatty acids $\left(\mathrm{C}_{17: 0 \Delta 9 \mathrm{c}}, \mathrm{C}_{19: 0 \Delta 9 \mathrm{c}}\right.$, and $\left.\mathrm{C}_{19: 0 \Delta 11 \mathrm{c}}\right)$, where $\mathrm{c}=$ cis, in the cytoplasmic membrane.

${ }^{6}$ Unsaturated fatty acids $\left(\mathrm{C}_{16: 1}, \mathrm{C}_{18: 1}, \mathrm{C}_{18: 2 \mathrm{n} 6}\right.$, and $\left.\mathrm{C}_{18: 3 \mathrm{n} 3}\right)$ in the cytoplasmic membrane.

${ }^{7} \mathrm{SFA}\left(\mathrm{C}_{14: 0}\right.$, iso- $\mathrm{C}_{15: 0}$, anteiso- $\mathrm{C}_{15: 0}, \mathrm{C}_{16: 0}$, iso- $\mathrm{C}_{16: 0}, \mathrm{C}_{17: 0 \Delta 9 \mathrm{c}}, \mathrm{C}_{18: 0}, \mathrm{C}_{19: 0 \Delta 9 \mathrm{c}}$, and $\left.\mathrm{C}_{19: 0 \Delta 11 \mathrm{c}}\right)$ in the cytoplasmic membrane.

${ }^{8}$ PUFA $\left(\mathrm{C}_{18: 2 n 6}\right.$ and $\left.\mathrm{C}_{18: 3 n 3}\right)$ in the cytoplasmic membrane.

${ }^{9}$ Branched-chain fatty acids (iso- $\mathrm{C}_{15: 0}$, anteiso- $\mathrm{C}_{15: 0}$, and iso- $\mathrm{C}_{16: 0}$ ) in the cytoplasmic membrane.

${ }^{10}$ Ratio of unsaturated to saturated FA in the cytoplasmic membrane.

${ }^{11}$ Ratio of iso- to anteiso BCFA in the cytoplasmic membrane. 
grown at $8^{\circ} \mathrm{C}(7.1 \%)$ compared with $37^{\circ} \mathrm{C}(0.8 \%)$. The CMFA profiles of $L$. casei M36 grown in $4 \mathrm{mCCE}$ at $8^{\circ} \mathrm{C}$ unsupplemented or supplemented with $1 \%$ milk fat, the MAG mixture, or Tween 80 are very different. Of particular relevance are the significant alterations in percentages of CFA, BCFA, PUFA, and ratios I:A and $\mathrm{U}: \mathrm{S}$, which ranged from 2.3 to $21.0 \%, 2.0$ to $7.1 \%, 0.2$ to $5.2 \%, 1.0$ to 2.3 , and 0.07 to 0.85 , respectively (Table 2 ). These results suggest that $L$. casei M36 grown in $4 \mathrm{mCCE}$ at $8^{\circ} \mathrm{C}$ uses different strategies to accomplish homoviscous adaptation depending on the FA content of the supplement.

\section{CONCLUSIONS}

This study demonstrated that growth of $L$. casei in $4 \mathrm{mCCE}$ was significantly affected by temperature and that $4 \mathrm{mCCE}$, without supplementation, is not suitable as a model system at temperatures representative of ripening Cheddar cheese (i.e., $8^{\circ} \mathrm{C}$ ). The addition of Tween $80,1 \%$ milk fat, or a MAG mixture resulted in a significant increase in the final cell density of $L$. casei in $4 \mathrm{mCCE}$ at $8^{\circ} \mathrm{C}$, suggesting that exogenous FA are important for growth of $L$. casei under conditions present in ripening Cheddar cheese. Additionally, these results support that milk fat typically provides the required exogenous FA in ripening cheese. The exogenous FA were incorporated into the cytoplasmic membrane and hence likely stimulate growth by significantly reducing the energy needed for FA biosynthesis. The FA present in the cytoplasmic membrane, either from exogenous sources or de novo FA synthesis, are then modified to generate a CMFA profile that allowed for growth at $8^{\circ} \mathrm{C}$. Subsequent studies examining the strain-specific contributions of SLAB and NSLAB to Cheddar cheese flavor development, as well as the effects of cheese composition and ripening regimen on the Cheddar cheese microbiota and flavor development, will be conducted in CCE supplemented with $1 \%$ milk fat.

\section{ACKNOWLEDGMENTS}

This research was supported by Dairy Management Inc. (Rosemont, IL), through the Wisconsin Center for Dairy Research, and by the National Institute of Food and Agriculture, United States Department of Agriculture, under ID number WISO1347.

\section{REFERENCES}

Annous, B. A., L. A. Becker, D. O. Bayles, D. P. Labeda, and B. J. Wilkinson. 1997. Critical role of anteiso- $\mathrm{C}_{15: 0}$ fatty acid in the growth of Listeria monocytogenes at low temperatures. Appl. Environ. Microbiol. 63:3887-3894.
Boucher, B., C. Brotherson, and J. R. Broadbent. 2006. Effect of starter and nonstarter lactic acid bacteria on medium redox. Aust. J. Dairy Technol. 61:116-118.

Broadbent, J. R., K. Houck, M. E. Johnson, and C. J. Oberg. 2003. Influence of adjunct use and cheese microenvironment on nonstarter bacteria in reduced-fat Cheddar-type cheese. J. Dairy Sci. $86: 2773-2782$

Broadbent, J. R., R. L. Larsen, V. Deibel, and J. L. Steele. 2010. Physiological and transcriptional response of Lactobacillus casei ATCC 334 to acid stress. J. Bacteriol. 192:2445-2458.

Budinich, M. F. I. Perez-Diaz, H. Cai, S. A. Rankin, J. R. Broadbent, and J. L. Steele. 2011. Growth of Lactobacillus paracasei ATCC 334 in cheese model system: A biochemical approach. J. Dairy Sci. 94:5263-5277.

Cai, H., R. Thompson, M. F. Budinich, J. R. Broadbent, and J. L. Steele. 2009. Genome sequence and comparative genome analysis of Lactobacillus casei: Insights into their niches-associated evolution. Genome Biol. Evol. 1:239-257.

Chattopadhyay, M. K., and M. V. Jagannadham. 2003. A branched chain fatty acid promotes cold adpatation in bacteria. J. Biosci. $28: 363-364$

Christensen, J. E., and J. L. Steele. 2003. Impaired growth rates in milk of Lactobacillus helveticus peptidase mutants can be overcome by use of amino acid supplements. J. Bacteriol. 185:3297-3306.

Christie, W. W. 2000. Lipid Analysis: Isolation, Separation, Identification and Structural Analysis of Lipids. Oily Press, Bridgwater UK.

de Man, J. C., M. Rogosa, and M. E. Sharpe. 1960. A medium for the cultivation of lactobacilli. J. Appl. Microbiol. 23:130-135.

Díaz-Muñiz, I., D. S. Banavara, M. F. Budinich, S. A. Rankin, E. G Dudley, and J. L. Steele. 2006. Lactobacillus casei metabolic potential to utilize citrate as an energy source in ripening cheese: A bioinformatics approach. J. Appl. Microbiol. 101:872-882.

Díaz-Muñiz, I., and J. L. Steele. 2006. Conditions required for citrate utilization during growth of Lactobacillus casei ATCC334 in chemically defined medium and Cheddar cheese extract. Antonie van Leeuwenhoek 90:233-243.

Farrell, J., and A. Rose. 1967. Temperature effects on microorganisms. Annu. Rev. Microbiol. 21:101-120.

Folch, J., M. Lees, and G. H. S. Stanley. 1957. A simple method for the isolation and purification of total lipides from animal tissues. J. Biol. Chem. 226:497-509.

Fox, P. F., P. L. H. McSweeney, and C. M. Lynch. 1998. Significance of non-starter lactic acid bacteria in Cheddar cheese. Aust. J. Dairy Technol. 53:83-89.

Hulbert, A. J. 2003. Life, death and membrane bilayers. J. Exp. Biol. 206:2303-2311.

Jordan, K. N., and T. M. Cogan. 1993. Identification and growth of non-starter lactic acid bacteria in Irish Cheddar cheese. Ir. J. Agric. Food Res. 32:47.

Kaneda, T. 1991. Iso- and anteiso-fatty acids in bacteria: Biosynthesis, function, and taxonomic significance. Microbiol. Rev. 55:288-302.

Makarova, K., A. Slesarev, Y. Wolf, A. Sorokin, B. Mirkin, E. Koonin, A. Pavlov, N. Pavlova, V. Karamychev, N. Polouchine, V. Shakhova, I. Grigoriev, Y. Lou, D. Rohksar, S. Lucas, K. Huang, D. M. Goodstein, T. Hawkins, V. Plengvidhya, D. Welker, J. Hughes, Y. Goh, A. Benson, K. Baldwin, J. H. Lee, I. Díaz-Muñiz, B. Dosti, V. Smeianov, W. Wechter, R. Barabote, G. Lorca, E. Altermann, R. Barrangou, B. Ganesan, Y. Xie, H. Rawsthorne, D. Tamir, C. Parker, F. Breidt, J. Broadbent, R. Hutkins, D. O'Sullivan, J. Steele, G. Unlu, M. Saier, T. Klaenhammer, P. Richardson, S. Kozyavkin, B. Weimer, and D. Mills. 2006. Comparative genomics of the lactic acid bacteria. Proc. Natl. Acad. Sci. USA 103:15611-15616

Mallmann, W. L., and S. A. Broitman. 1956. A surface plating technic for determining bacterial population of milk. Am. J. Public Health 46:1018-1020.

Mayra-Makinen, A., and M. Bigret. 1998. Industrial use and production of lactic acid bacteria. Page $73-102$ in Lactic Acid BacteriaMicrobiology and Functional Aspects. 2nd ed. Marcel Dekker Inc., New York, NY. 
O'Fallon, J. V., J. R. Busboom, M. L. Nelson, and C. T. Gaskins. 2007. A direct method for fatty acid methyl ester synthesis: Application to wet meat tissues, oils, and feedstuffs. J. Anim. Sci. $85: 1511-1521$.

Patton, S., and G. E. Huston. 1986. A method for isolation of milk fat globules. Lipids 21:170-174.

Sajbidor, J. 1997. Effect of some environmental factors on the content and composition of microbial membrane lipids. Crit. Rev. Biotechnol. 17:87-103.

Suutari, M., and S. Laakso. 1992. Temperature adaptation in Lactobacillus fermentum: Interconversions of oleic, vaccenic and dihydrosterulic acids. J. Gen. Microbiol. 138:445-450.
Tukey, J. W. 1949. One degree of freedom for non-additivity. Biometrics 5:232-242.

Wang, L., and E. A. Johnson. 1992. Inhibition of Listeria monocytogenes by fatty acids and monoglycerides. Appl. Environ. Microbiol. 58:624-629.

Zhang, Y. M., and C. O. Rock. 2008. Membrane lipid homeostasis in bacteria. Nat. Rev. Microbiol. 6:222-233.

Zwietering, M. H., I. Jongenburger, F. M. Rombouts, and K. van't Riet. 1990. Modeling of the bacterial growth curve. Appl. Environ. Microbiol. 56:1875-1881. 